\title{
The Ethnic Minority Question and Rohingya Crisis in Contemporary Myanmar
}

\section{KUNAL MUKHERJEE}

\begin{abstract}
The recent humanitarian Rohingya crisis has once again put Myanmar onto the centre stage of global media attention. The aim of this paper is to look into the ethnic minority question in contemporary Myanmar. The paper has a special focus on the Muslim Rohingya community. The paper argues that problematic race relations in Myanmar today should not be viewed in isolation but should be seen as a part of a historical continuum. The British colonial policies of divide and rule, political leaders and their obsession with Buddhism in the postindependence period and xenophobic tendencies during the long years of the military junta have all collectively contributed to the very complex situation in which the country finds itself today when it comes to race relations. Meaningful democracy and economic development have been advocated as the way forward especially for the more peripheral parts of the country where there is a strong ethnic minority presence.
\end{abstract}

Keywords: Myanmar, Ethnic Minorities, Rohingya, South East Asia, Repression

\section{Introduction}

For over half a century Burma had been closed to the international community. The country only recently opened up its doors to the outside world in 2011 when the process of democratization started to take place. However, the outbreak of the recent humanitarian Rohingya crisis in recent years in the western Rakhine province has once again put the country onto the centre stage of international affairs and media attention. Over the past few months the Burmese government has been at the receiving end of international condemnation because of governmental brutality directed at the Rohingya community. The aim of this paper is to firstly look at the situation of ethnic minorities in contemporary Myanmar focussing especially on the Muslim Rohingya community. 'National races or taingyintha is amongst the pre-eminent political ideas in Myanmar today.'

Kunal Mukherjee, Ph.D. is a Lecturer in International Relations/Asian Politics at Lancaster University, England, U.K. He has been working for the PPR (Politics, Philosophy and Religious Studies) Department at Lancaster University as a full-time member of faculty since 2011. He has an interest in both South Asia as well as East Asia. He has published over 25 single authored scholarly articles on different aspects of Asian politics and security in peer reviewed academic journals. 
Secondly, there is special focus on Indian media reporting and how The Telegraph in particular, an English newspaper based in the eastern city of Kolkata, has reported the crisis. The paper argues that the current Rohingya humanitarian crisis should not be seen in isolation but should be analysed within a certain historical context and should be seen as a part of a historical continuum. The crisis or any form of ethnic tension in Myanmar today can be traced back to British colonial times when colonial authorities followed a policy of divide and rule and favoured ethnic minorities over the ethnic majority. However, the British are not the only ones to blame. Xenophobic tendencies can be seen in Myanmar even after independence. These tendencies have been expressed mainly by the political and military elite especially in the sixties when there was an open dislike for all things considered foreign. The Rohingya crisis needs to be analysed within this context and should be seen as a part of a historical continuum. Before we look at the situation of ethnic minorities in contemporary Myanmar it is important to have at least some understanding of the country's political history which will set the context and the situation of minority communities needs to be located within this context. In other words, the historical background will help us to understand the more recent developments better. It should be mentioned at the very outset that the words, 'Burma' and 'Myanmar' in this paper have been used interchangeably.

\section{The Colonial Years}

It is important to note that Burma had been colonised by the British in the $19^{\text {th }}$ century. Britain's initial connections and involvement with Burma primarily took place through exploratory and defensive moves on part of the East India Company. Britain's interest in Burma was primarily related to commerce and business. Profit motive was at the heart of British imperial policy in mainland South East Asia. Imperial Britain's initial preference had been for some sort of informal control rather than to have direct control and authority over Burma. Before reaching Burma the British had extended its sway over the Indian subcontinent. Britain was able to establish its hegemony in the Indian subcontinent through both diplomacy and war. When diplomacy failed, it became essential for imperial Britain to wage war. Britain extended its rule over Burma in a similar way and fought three wars before it was able to exercise its full control. The first Anglo-Burmese War was fought between the years 1824 and 1826. The second Anglo Burmese War was fought in 1852. And the third and final Anglo Burmese War was fought in the year 1885 .

The process of taking over Burma was gradual. In the first instance, the Arakan in the west (which is today's Rakhine province), and Tenasserim in the south were captured. In the second instance, the former capital city, Rangoon and the Irrawaddy delta fell to the British, thus placing what the colonial authorities used to call 'lower Burma' or the seaboard under colonial rule. And finally, after the war in 1885, upper Burma or the more interior parts of the country was captured which included places like Mandalay. In the early years, Britain's new imperial possessions were governed piecemeal. In the 1820's, Burmese lands were governed from Penang in Britain's strait settlements. ${ }^{2}$ For a long time, Burma was governed from the city of Calcutta, now known as Kolkata, which had been the capital city of British India before 
Delhi became the capital of India. For a long time Burma was seen as the backwaters of Bengal Presidency. Burma was brought within British India very quickly, of which it remained a part until 1937. Purposeful development took place after the second Anglo Burmese War, 1852. After the third Anglo Burmese War, 1885, widespread administrative reform started to take place. Self-government came to Burma very slowly. The government of Burma act of 1935 provided for the Burmese territory to be separated from India and was given a distinct colonial identity by 1937 .

Imperialism was to have a long lasting impact on Myanmar, and whilst there were some positives, the eventual impact on Burmese society was hugely negative. Since Burma was seen as the backwaters of Bengal Presidency, the people were often classified as barbaric and uncivilised where chaos and lawlessness was the order of the day. Because of this, the British colonial authorities started with their pacification campaigns. Pacification was judged to have been complete by the year 1890. 1920 was the year when the nationalist movement against British colonialism had almost reached its peak. Between these years, 1890 and 1920, the British colonial authorities had achieved many of their objectives. First of all the authorities had managed to secure a measure of law, stability and order across the land. Secondly, they mapped their new territorial possession. Thirdly, they rationalised administrative structures in the core. Fourthly, they set Burma on the path of economic growth and development. And finally, they exposed Burmese society to global market forces.

\section{The Pacification Campaigns}

Order was enforced in the new colonial territory through a series of pacification campaigns which had been designed to impose passivity, security and stability. This was formally concluded in 1890. It gave way to the permanent stationing of British security and military personnel in the Burman core. Burmese villagers and peasants were all subjected to colonial rule more directly. This rule would often turn violent which created a lot of hostility and acrimony between the two sides. Power was mainly concentrated in the hands of the colonial officials. In a province widely known to be a very lawless part of the British Empire, the pacification campaign paved the way for sufficient order and stability which was very much required for the core purposes of British imperialism. The policies taken by Britain in Burma were actually quite similar to the policies which had been taken in neighbouring South Asia. At a much earlier time Lord Wellesley had introduced the subsidiary alliance in British India. By this policy, British security personnel were to be stationed at the court of a princely ruler. Indian rulers were not meant to go to war with one another without keeping the British informed. There was also meant to be the stationing of a British resident at the court who was not supposed to interfere in the internal policies and domestic matters of the kingdom. The Indian ruler had to pay for these British troops who in turn supposedly provided security and protection to the Indian ruler. The so called alliance did not work out in the end. The British resident started to interfere in internal matters. Maintaining the British troops became very expensive and this impoverished the Indian ruler paving the way for antagonistic relations between the British and the Indians.

\section{Mapping Burma}


Mapping Burma was a large and strenuous exercise undertaken through an extension of the Great Trigonometrical Survey of India. The process involved negotiating external frontiers predominantly with China in the north and imperial France in the east since the French had a presence in Indo-China. In a land containing a wide range of ethnic minorities and linguistic communities never before treated as a single political entity, the British solution to this was to carve out a Burman core and a patchwork of peripheral minority groups. Colonial officials termed the central plains Burma proper and the surrounding peripheral areas as the Excluded Areas. The Excluded Areas geographically were often mountainous and hilly and soon took on the label of Scheduled Areas.

At the end of the colonial period they were known as the Frontier Areas. In Burma proper lived Burma's ethnic majority population and in the more peripheral parts were the places where the ethnic minorities lived. Often the ethnic groups who reside in the more peripheral parts or what used to be called the Excluded Areas have a sense of one-ness and identification with their ethnic brothers living across the international border in India in the west, China in the north and Thailand in the east. Of the two major mapping exercises, the external frontiers turned out to be the most durable. 'The territorial boundaries of Myanmar are the creation of British colonialism. Prior to British conquest no indigenous kingdom controlled the territory that now comprises Myanmar. ${ }^{3}$

\section{Rationalisation of Administrative Structures}

'The colonial attempt to rationalise administrative structures was variegated and partial. ${ }^{4}$ In central Burma, traditional authority structures were largely destroyed following the expulsion of King Thibaw at the end of 1885. The traditional political institutions like the monarchy, the nobility, the army and the royal agencies soon disappeared. In the countryside, local ruling families, many of whom had governed for centuries lost their positions as hereditary status came to an end. By contrast, in the more hilly Excluded Areas like the Kachin state in the north, the existing authority structures were kept in place. Britain adopted a kind of indirect rule through princes, the nobility, and village chiefs. Holliday writes, 'The British...incorporated Burma into the Raj for most of the colonial period, paid little heed to traditional ruling structures in some parts and worked closely with and through them in others, and consequently established divergent modes of direct rule in central Burma and indirect rule in the surrounding hill country. ${ }^{5}$

\section{Economic Growth and Development}

A major change introduced by the British was economic development and putting Burma on the path of economic growth. The delta region in this context deserves special mention. This rice frontier was an engine of colonial economic growth throughout the latter half of the 1800's and first half of the 1900's. Britain introduced the liberal economic framework in Burma as they had done in India. Special measures were designed to accommodate capitalist expansion. Considerable infrastructure investment was made e.g. the railways which had been introduced between 1870 and 1915 . The delta region was extremely fertile and finally exposed to foreign exploitation. As a result of this, we see the rise of the money economy and economic growth 
eventually turns Burma into the rice basket of Asia. Social change saw the internal migration of people from the more interior parts or upper Burma to lower Burma thereby boosting the delta population. The other great imperial industries included mainly oil and forestry, mainly teak. These, however, were nowhere close to the size of the rice industry.

\section{Exposure to the Global Economy}

Finally, Burma was opened up to the rest of the world and was exposed to global society by the British. Till this point of time in history, Burma had been relatively isolated and remote and a predominantly closed society. Geographically, it remained cut off from the outside world because of its extensive coastlines and high mountains. Making Burma a part of British India in the early years created a single colonial market for goods, services and labour. Burma was opened up for business on several fronts that enabled both entrepreneurs and workers to seek their fortune in Burma proper. Small numbers of Europeans also settled here. Alongside came many Chinese and Indians. Traders and entrepreneurs far outnumbered civil servants and bureaucrats. Richard Cockett writes, 'and since colonial Burma was administered as part of Britain's Indian empire, the vast majority of newcomers to Rangoon, and to Burma more generally, were consequently Indian, or rather disparate peoples, Hindu, Muslim and more, who made up British India. There was nothing to stop the influx. Indeed, it was encouraged by the British colonialists. ${ }^{6}$ This was similar to British colonial policies in Assam in north east India where tribal groups like the Mundas and Santhals had been encouraged to move from India proper to Assam to work in the tea plantations which had been discovered by the British as a lucrative business. Most outsiders saw Burma as a place to do business. Major cities were transformed or created and Rangoon became a global commercial centre populated by foreigners. Rangoon was now linked by sea to a network of British ports in other Asian colonies. In other words, Rangoon became a foreign city on Burmese soil.

\section{The Impact of Colonialism}

Although from the discussion so far it sounds as if the British reforms in Burma was a success story, it could be argued that the core triumphs of British imperialism were also the source of its destruction and downfall. The imposition of order did not succeed in generating social support for the British. The approach was too top-down and coercive. In other words, statesociety relations became coercion intensive. A policy of might is right can never work for long. The mapping exercise driven above all by administrative convenience entrenched ethnic cleavages and exacerbated racial divides. The so called rationalisation of administrative structures in the Burmese heartland weakened support for the British. While senior positions were filled in by the Europeans, other ranks were filled in by ethnic minorities from the more peripheral parts of the country. Burman participation in the state and army was very clearly limited. The British clearly favoured the ethnic minorities and discriminated against the ethnic majority Burman groups as a part of their policy of Divide and Rule. The exclusion of the Burman's from the state and military service proved to be catastrophic. Soon a powerful ethnic majority nationalism based narrowly on Buddhism and Burmese speaking people took root which was not very kind to the ethnic minority 'other'. Economic growth set the stage for recession and tension. Capitalism undermined traditional institutions and ways of life and also 
promoted a nationalist reaction. And finally, opening up the whole of Burmese territory to the outside world gave rise to a virulent nationalist backlash that had profound implications for Burma in the post-colonial period. The race riots started in the 1930's, with serious IndoBurmese violence in 1938/1939, resulting in two hundred deaths mainly of Indian Muslims and creating much racial tension. 'Anti-Muslim riots belong to a wider phenomenon of protests against foreigners. The first riots with an anti-Muslim element go back to protests against the labour migrations the imperial British had encouraged. The incidents of 1930 and 1938 were sectoral affairs directed against migrant Indian harbour workers by unemployed Burmese. Burmese nationalists turned them into propaganda material with the slogan, 'Burma for the Burman. ${ }^{77}$ When construction of the Yunnan-Burma Railway started in 1938, there was fear of Chinese immigration spreading across Burma.

\section{The Rising Tide of Burmese Nationalism}

The British reforms collectively strengthened nationalist sentiment in Burma. The Young Men's Buddhist Association came into existence in Rangoon in 1906 and was founded by English reading school boys. It was superseded in 1920 by the General Council of Burmese Associations. Inspired by Gandhian resistance in neighbouring India and led by U-Ottama, Burma's first great nationalist hero, a new generation of political monks rose to challenge British imperialism. Although Britain decided to grant India self-rule in 1918 due to its wartime contribution, the Burmese were seen as another race and at a different stage in their political development. Nationalist reaction grew stronger in the 1920's and 1930's. Between the years 1930-1932, a peasant rebellion led by monk Saya San resulted in the capture of nine thousand rebels, the death or wounding of three thousand, and the conviction and hanging of about three hundred and fifty. Across the decade, the Dobama Asiayone or We Burman's Association fed student and worker protest. Formed around 1930, it encouraged members to add the honorific title of thakin to indigenous names to undermine and ridicule British official insistence on formal modes of address. 'The Student Strike of 1920, the Saya San Rebellion, the Dobama movement, Aung San and the Student Strike of 1936 occupy centre stage in conventional accounts of Burman nationalism. ${ }^{8}$ As the nationalist movement gained in momentum and a militant side developed, the gaze of the Burmese leaders fell on Japan for vanguard action. Reactive nationalism against the British fed into the Japanese recruitment of a group of young radicals. 'There was little contact between the two states of Japan and Burma before Japan began its imperialist expansion in the late $19^{\text {th }} /$ early $20^{\text {th }}$ century. ${ }^{, 9}$ Led by Aung San in 1941, the 'thirty comrades', formed the core of the Burma Independence Army that fought alongside the Japanese in 1942 and helped in a matter of months to destroy British rule. The participation of the BIA in the defeat of the colonial administration gave its officers and men great status and prestige. ${ }^{10}$ However, with the passage of time, the Japanese were becoming increasingly oppressive and unpopular. 'The honeymoon period between the Imperial Japanese Army and Aung San's Burmese Independence Army was short-lived.' ${ }^{11}$ Finally, the Burma Independence Army decided to switch sides. In 1945, the BIA joined hands with the Allies and drove the Japanese out of Burma. Eventually, Japan suffered a crushing defeat.

\section{Burma in Transition}


In the post war order, the colonial divide between Ministerial Burma and the Scheduled Areas became a critical issue. After the British had left there were talks of a two Burma principle. Burman leaders began from the assumption that Burma was one nation with a diverse range of ethnic groups that had been separated from the Burman core due to the colonial policy of divide and rule. The Burmans could not obtain independence without reaching an agreement with the hill tribes. The hill tribes, who would have preferred to revert to the status quo ante, the light touch of British rule, were made to understand that this was not an option. The Karen, whose lands had been ravaged by both Japanese and Burmese troops during the war, refused to contemplate a union with the Burmans. ${ }^{12}$

In May, 1946, the Anti-Fascist People's Freedom League called for a conference of representative of all peoples for the purpose of discussing freely the establishment of the Union of Burma. In Panglong on the $12^{\text {th }}$ of February, 1947, Aung Sang joined representatives of minority groups to sign a brief document which officially recognised the formal autonomy of these groups. The $12^{\text {th }}$ of February is now celebrated in Myanmar as Union Day. The incoming leader of the AFPFL, $\mathrm{Nu}$, made a personal pledge to ethnic minorities regarding future fair dealings. Transfer of sovereignty was made for fourth of January, 1948. The emphasis was on the Union of Burma rather than on the separate status of non Burman people. This was both a victory for nationalist leaders as well as a source of controversy in the post-independence period. 'Indeed the armed forces have continuously claimed that the British instituted a policy of 'divide and rule' among ethnic groups that resulted in today's mistrust among the Burmans and the minorities.' 13

Between the years 1945 and 1948, nationalism was more Burmese than Burman and it focussed on bringing people and different ethnic groups together. Sadly, with the passage of time, this changed. Within this broad nationalism, there were more exclusive dynamics. Prominent among them was an attempt to reassert identity with a strong tendency to look back to a glorious mono ethnic past rather than looking forward to a multi ethnic future. Equally present throughout was a series of ethnic minority identities that would challenge Burman nationalism post 1948 . Holliday writes, 'in both majority and minority populations, the reform process launched in earnest in 2011 has often seen a hardening, not softening, of ethnic and religious identities.' 14

The country was also characterised by social disintegration due to the impact of colonialism and capitalism. Excessive militarisation during the Second World War paved the way for easy access to weapons. Many ethnic minority groups have waged an on-going insurgency against the Burmese government since the fifties and were able to do so because of easy access to weapons. Guan writes, 'Since attaining independence in 1948, the Burmese government has been struggling with uneven success to preserve the unity of the country. ${ }^{, 15}$ There was also the proliferation of pocket armies. In many places the government had to sponsor peace guerrillas as agents of order. Since 1948, the Burman core has had to deal with two major internal challenges: communist mobilisation and ethnic rebellions.

At a superficial level, it seemed that Burma was making progress after 1948. A state bureaucracy was rebuilt and an indigenous judiciary put in place. A Burmese welfare state 
began to emerge and other sectors also experienced expansion. Civil society began to develop and village life also picked up due to the introduction of some land reforms. However, behind all of this, political and administrative structures functioned poorly. Corruption was pronounced and there was marked distrust. Government structures were divided. 'For over five decades the economy plummeted and many sectors of society, including education, suffered from political interference and financial neglect. ${ }^{16}$ There was also hostility towards Burmanisation policies associated with the AFPFL. Due to the fragmentation within the AFPFL, the party failed to bring about any semblance of unity. Nu's obsession with Buddhism and his attempt to make it the state religion made him unfit for politics. 'Possibly he believed that it would assist in unifying a country divided on political and ethnic lines. ${ }^{, 17}$

All these factors allowed the military to take over in the early sixties. The military had a strong position as a result of historical accident. This relates to the way the Cold War played out on Burmese soil in the wake of the Chinese Communist Revolution in 1949. Although Mao's troops drove out the nationalists and Chiang Kai Shek to Taiwan, a large contingent remained trapped in the Yunnan province in 1951 and also took shelter in the Shan and Kachin states of Myanmar. In relation to Sino-Burmese relations, Holliday writes, 'Relations became more fraught when China chose to support the rebel Communist Party of Burma in the 1950 's. ${ }^{18}$ As a result of this, Nu's government sought urgently to create a force capable of protecting Burma's borders and securing national sovereignty. As the Cold War threatened to swallow up Burma, the civilian and military leaders had few choices but to redeploy the security apparatus to hold a country that was on the verge of disintegration and crumbling. This set the stage for the rule of the military in contemporary Myanmar. One key step was the incorporation of pocket armies, village defence units, forest guards, power station guards and the union military police into the military.

Burma's democratic phase lasted from 1948 till 1962. Ne Win launched a coup d'etat in 1962. Before he came into power, Burmese soldiers viewed themselves as state builders. It was their task to secure territorial integrity. It fell upon them to shape the institutions of the government. Through them alone could a patriotic spirit be cultivated. They created a state within a state, a society within a society and gradually expanded their influence into different sectors of the economy. Even today, structures of military hospitals, schools and welfare services exist across the country. Attempts were made to nationalise major businesses between 1962 and 1963. Although everyone talks about the hostility directed towards ethnic minorities today in contemporary Myanmar especially in relation to the Rohingya community, as early as the sixties there had been revulsion to western ways and xenophobic tendencies had taken root. For instance, in 1962, Ford, Fulbright and Asia Foundation activities had been terminated. In 1964, English medium schools were banned. Elite private schools were taken into public ownership. Libraries run by India, Russia, the UK and the US were closed down by 1965 . Visas for western tourists were restricted. Between 1963 and 1964, an estimated 300, 000 Indians fled following nationalisation of their trading concerns.

From 1964, under the orders of Ne Win, hundreds and thousands of men, women and Children were sent back to India and Pakistan. 'The Indian government under the last year of Pandit Nehru's leadership accepted Ne Win's desire to send these people away, and special 
ships and planes were chartered on New Delhi's order to bring them home.'19 Large scale joint ventures with private firms ended in 1965. Burma Corporation and Burma Unilever were nationalised. We see the rise of the command economy. The critical rice sector was placed under strict control. Ideological rigidity became pervasive and exports collapsed in the sixties. Greater problems were experienced in meeting people's core needs. Many Chinese also left especially after the race riots that took place against the Chinese in 1967. It was similar to Idi Amin's expulsion of Asians from Uganda. Political conversations with other ethnic groups also stopped.

However, from the seventies onwards we see the military government given a civilian makeover and the country begins to build bridges with its neighbours and starts to open up. By the late seventies foreign aid increasingly flows into the country and English returns as the medium of instruction alongside Burmese. The Burman majority population has been engaged in a struggle for democracy and major protests have taken place in 1962, 1967, 1970, 1974, 1988, 1996 and 2007. When revolts have exploded and protest movements have come to the political forefront, it has often been a product of economic discontent and high levels of corruption amongst the political elite and administrative failure on part of the government. The focal point has generally been Rangoon, although open rebellion and protests have spread to other urban centres as well.

The Burma Army is commonly called the Tatmadaw. Initially, the name taken was SLORC: State Law and Order Restoration Council (1988-1997). Later it became the SPDC until 2010 which was the State Peace and Development Council. 'The Tatmadaw (the Myanmar Armed Forces) is the most resilient military regime of the contemporary era. Defined by strong personalist rule, the Tatmadaw has been the central political actor in Myanmar for the last half century. ${ }^{20}$ In 1989 they changed the name of the country from Burma to Myanmar although changing the name did not have the support of the people. 'Opponents of the military junta refused to recognise the change of the country's name to Myanmar, made unilaterally by military leaders in 1989. ${ }^{21}$ It was not until 2011 that any attempt was made to give state structures some detachment from the military apparatus. 'Conflict along religious lines has been one of the most controversial features of the country's transition. ${ }^{22}$ Since the sixties, the main priority was to control political space and push back any kind of opposition. It was in the context of political strikes and mass meetings that Aung Saan Suu Kyi came into power. She called for the dismantling of the one party system, and that a multi-party system be established and also called for free and fair elections. Traditionally, challenges to the authoritarian regime in Myanmar have come from democratic groups and ethnic minorities. Initially, the SLORC had 19 members under Saw Maung, who held the chairmanship until 1992. Then Than Shwe remained paramount ruler till 2011. Even within its own tight membership it rarely established complete unity. Nevertheless, the Tatmadaw did succeed in bringing about some unity to sustain its position as the dominant political institution within the state. The state through the SPDC sought to exercise control over four overlapping domains: political, administrative, military and social. Throughout contemporary Burmese history there has always been some grassroots support for the military. For instance, by emphasising its Buddhist credentials and casting itself as the defender of rural interests in a country which is predominantly agrarian the 
military built up pockets of support. Through diverse interactions between the junta and society, multiple images of the junta emerged. Sometimes poor rice farmers prized central authority as protection from petty abuse and exploitation.

From the very beginning, the Myanmar military has held a political position through the Tat tradition in Burmese politics. During the struggle against the British, Burmese nationalists and political activists formed various Tats or private pocket armies to back up their political activities. Tat formation became very vigorous in the late 1930's when Burmese nationalists began to realise the importance of armed struggle as a part of their overall political struggle against British imperialism. Hence, the Tat tradition in politics became the norm in the post-colonial period. By the 1950's, Tats carried guns and were controlled by individuals or parties. Various paramilitary Tats were also formed by the government. 'Therefore, the genealogy of the Tatmadaw can be traced back to the national struggle for independence, and the employment of the Tatmadaw as a political force... Many Myanmar politicians have joined the Tatmadaw since its inception in December, 1941. ${ }^{23}$

The generals preferred to cloak their rule in legality by using codes from earlier times. For instance, the Unlawful Associations Act of 1908 allowed the head of state to declare any organisation as illegal. The Official Secrets Act of 1923, provided for jail terms up to fourteen years for anyone found in possession of information which was seen as anti the state/state interests. Emphasis was placed on unity by the junta. The points that were emphasised by the military included: non-disintegration of the union, non-disintegration of national solidarity and perpetuation of sovereignty. The leading generals have always argued that this was the only way out and route to salvation for a country as divided as Myanmar. When SLORC took power, Tatmadaw repression ensured that NLD/National League for Democracy leaders not killed on the streets were hunted down relentlessly. Some ten thousand fled to ethnic nationality areas and soon gathered on border camps in India and Thailand to plan counter offensives.

Many pro-democracy leaders or ethnic minority leaders have been jailed or sentenced to prison for 15 years or more. Jails gradually became packed with political prisoners. Student activism was crushed. Protests carried on in 2007 against poverty. The ethnic minority areas were especially the more impoverished parts of the country. Key figures like Min Ko Naing and Ko Ko Gyi were arrested and sentenced to prison. This was the stimulus for the Saffron uprising. Buddhist monks led demonstrations against the high cost of living in the monastery town of Pakokku. Dissent spread to various parts of the country and crackdown soon followed. As late as 2003, the list of offences that could land an individual in prison included: telling jokes about the military, writing poems about democracy, blogging about injustices, reporting about oppressive practices, holding a gathering of more than five people, marching peacefully to protest high gas prices, being a member of the 1988 student protests, making a documentary about orphans from environmental disasters and cyclones, providing medical care for AIDS victims without approval, taking photos of military installations or troops, carrying a sign protesting the house arrest of Aung San Suu Kyi, posting a cartoon of General Than Shwe on a blog, speaking to journalists or international human rights groups, taking photos of human rights abuses, complaining to the International Labour Organisation about slave labour, praying 
in public for Aung San Suu Kyi's release, singing a song critical of the military and driving up to Aung San Su Kyi's house. ${ }^{24}$

In the more peripheral parts of the country ethnic armies continued fighting against the Tatmadaw. Walton writes, 'the military governments that ruled the country from 1962 until 2011 regularly battled ethnic insurgencies in the border areas and, despite a series of ceasefires over the last 15 years, ethnic conflict continues today. ${ }^{25}$ However, from 1989-1996, most major militias reached ceasefire deals with the SLORC, although sometimes under duress. Many of these agreements were often not signed nor made public and were actually quite informal in nature. There was tension especially in the year 2008 when the constitution provided for ethnic militias to form a Border Guard Force within the larger Tatmadaw. As a result of this the ethnic militias were now being subjected to central control. 'It meant a partial but not complete integration with the Burmese army. Acceptance would mean sweet business deals and a place for former rebel leaders in the new order. ${ }^{26}$ Ceasefire deals had considerably changed the landscape with the military strengthening its hold over Burmese society and politics. Ethnic nationality leaders turned to commercial ventures and the ethnic resistance against the military was marked by fragmentation and all sorts of divisions. For instance, the Karen National Union was challenged by breakaway groups from 1994 since it was unable to represent all shades of Karen opinion. In a few ethnic nationality areas local elites continued to exercise power. Regime strategists divided the country's land into white areas which were under military rule, brown areas which were seen as accessible to the government and insurgent groups and finally black areas which were controlled by the enemies of the state.

There had been extensive devolution of power in parts of the Shan state, brutal military occupation in the Rakhine state and parts of Karen, Kayah and Shan states and coexistence between central and local authorities in parts of the Kachin, Karen, Mon and Shan states. The situation on the ground was often much more complex. In reality, areas of disputed authority and influence often blurred into each other with frontiers shifting over time in accordance with the dynamics of state society relations and armed conflict. The Tatmadaw remained a grim reality in large parts of the country for much of the post-independence period but its rule was secure in some places and contested in other areas. The Muslim minority Rohingya people living in the Rakhine state which we will discuss in detail later were rendered stateless by successive governments and were often persecuted by state officials. They experienced an extreme form of human rights violations with rights to property, education, marriage and employment all curtailed. Pushed into Bangladesh or taking to the high seas often in flimsy boats for protection many suffered and were subjected to extensive abuse and some eventually died.

\section{The Ethnic Minority Question iln Contemporary Myanmar}

A nation of approximately fifty one million, Burma-Miyanmar is one of the most ethnically and religiously diverse countries of South East Asia. Besides the Burman Burmese speaking majority, there are seven major ethnic groups. These are the Karen, Karenni, Shan, Mon, Chin, 
Kachin and the Arakan. The Karen, Karenni, Shan and Mon are to the east and south, close to Thailand. The Kachin state lies in the north close to China. The Chin and Arakan states are both in the west close to India and Bangladesh. Smaller groups include the Naga, Lahu, Lisu, $\mathrm{Pa}-\mathrm{O}$ and the Rohingyas who are amongst the most persecuted. The situation in relation to the Rohingya community is so bad that it has often been compared to a genocide. ${ }^{27}$ Since independence in 1948 many of these ethnic groups have fought an armed struggle against the Burman dominated central government. Many of these groups feel excluded from the central decision making process and often feel that their voices are not heard. This has paved the way for secessionist groups to emerge and strengthen in the more peripheral ethnic minority parts of the country.

There are strong separatist tendencies amongst ethnic groups in Myanmar even today since many do not feel a sense of identification with mainstream Burmese society. 'Many among ethnic communities perceive the state as dominated by elements of the Burman (Bama) majority, which constitutes about two-thirds of the population. ${ }^{28}$ Often they feel a sense of oneness with their ethnic brothers across the international border with people in India. For instance, the Kachin's in Myanmar and the Naga's from India are predominantly Christian groups and a common religion often brings them and binds them together. The Kachin people also share common ethnic ties with the Jingpo people, a minority group in China. ${ }^{29}$ Due to cultural commonalities there are cross border connections and a feeling of disconnect with the Buddhist majority Burman core. In some cases ethnic minorities have fought for secession and in other cases many have fought for independence. But in almost all cases ethnic groups have fought for equal rights, autonomy and federal democracy within the Union of Burma.

Many signed ceasefires with the regime in the 1990's. But some groups like the Karen, Karenni, Shan and Chin have continued to varying degrees to fight until preliminary ceasefires were reached towards the end of 2011 and early 2012. Many of the ceasefire deals were broken. For instance, the Kachin had seventeen years of ceasefire from 1994 until the regime launched a fresh and brutal offensive against them in 2011. Efforts to secure a nationwide ceasefire have progressed painfully slowly. Nicholas Farrelly writes, 'The government led by President Thein Sein, a former senior Myanmar army officer who has previously commanded troops in border areas, is proud of the tentative ceasefires that have been arranged for war-ravaged parts of the country such as Kayin and Kayah states. Yet in some other areas his government has reignited hostilities: for example, in Kachin state where for almost two years (June 2011 to May 2013) the Kachin Independence Army was the target of government offensives. ${ }^{30}$

\section{The Karen}

The Karen community reside in south east Burma close to Thailand. Since 1949 they have been fighting an armed struggle for basic human rights, a degree of autonomy and more recently a battle for existence. 'The KNU/Karen National Union is Myanmar's oldest ethnic insurgency movement, which had posed a viable threat to the country's rulers with more than 10,000 well trained rebel soldiers for many decades since Myanmar's independence. ${ }^{31}$ One of the vice presidents of the KNU/Karen National Union, David Thackerbaw has been of the view that the state will eventually be wiped out. ${ }^{32}$ Historically, the Karen people had suffered centuries of 
oppression at the hands of the Burman kings. When the British started to colonise Burma in the first half of the 1800's, they saw the British primarily as liberators. The British also favoured them both in education and service. Their loyalty to the British has often angered the political elite in the Burman core. In the Second World War, they fought alongside the Allies in return for vague promises for independence or at least autonomy and protection after the war. Sadly, these promises were broken. But the Karen people decided to soldier on alone in their struggle for recognition and for their rights.

It was in 1950 when the Karens suffered their first setback when their leader, Saw Ba U Gyi was killed. Saw Ba U Gyi had trained as a barrister at Cambridge before returning to Burma to work as a civil servant. He established the four principles which included surrendering is out of the question, that the Karen people will retain their arms, that the recognition of the Karen state must be complete and that the Karen people will decide their own political destiny. In the 1960's it regained strength under the leadership of General Bo Mya, who dominated the KNU for the best part of four decades. The Karen struggle has continued through the decades till today. The Karen people have lived as captives in their own land and even when they have fled to the borders with neighbouring countries like Thailand, their security has been at risk. Padoh Mahn Sha, the General Secretary of the Karen National Union was shot by the Burmese military in the year 2008. He was one of the very few ethnic leaders who tried to bridge the divides between ethnicity, religion and politics and tried to unite people in pursuit of the cause of federal democracy and equal rights for all of Burma's people.

\section{The Kachin}

The Kachin community in northern Burma are mainly Christian and converted at the turn of the $20^{\text {th }}$ century by American Baptist missionaries. Like the Karen community, they also fought alongside the Allies. The Kachin Independence Organisation or the KIO is the main resistance group for the Kachin ethnic people. 'The Kachin brought jade and opium from Kachin state down to the Thai border to finance their purchases of arms and ammunition from Thailand. ${ }^{33}$ They had been subjected to the four cuts policy which aimed at trying to end access to food, funding, recruits and intelligence for the KIO and its armed wing, the Kachin Independence Army, the KIA. The Kachin state has almost become a war zone. They had signed a ceasefire with the regime in 1994, which had been broken in 2011. Human rights violations are common which include rape, religious discrimination, and forced labour and land confiscation. At least sixty thousand Kachin's were displaced from their villages. The situation has often been compared to a foreign invasion. The conditions of the camps of displaced people are critical and many are living in squalor and conditions of tremendous economic hardship. Although the United Nations had brought in some support, the people have been mainly dependent on the Kachin community for support. The Kachin people have found it extremely difficult to practise their Christian faith. Obtaining permission to build new churches or extending existing ones can be very difficult. The practising of the Christian faith by the Kachin people is often seen by military generals as an act of disloyalty and they have often been accused of following a colonial legacy.

\section{The Chin}


The Chin people are located in western Burma, close to the Indian state of Mizoram and also Bangladesh. They have been suffering at the hands of the regime on three counts: religion, ethnicity and politics. Since most Chin people are Christian they face religious discrimination. They tend to have more of a sense of oneness with the Mizo people in India who are also predominantly Christian. As a group with numerous pro-democracy organisations, the military has often viewed the Chin people unfavourably. They are often seen as recalcitrant elements in Burmese society like the Kachin and the Karen. Chin state is one of the poorest and is very remote geographically. It is one of the least developed parts of the country where healthcare and education is almost non-existent. The Chin people tend to construct crosses on hill tops, many of which have been torn down by the military. In places of the crosses the regime has built pagodas or Buddhist statues. To build these statues of the Buddha, sometimes Chin people have been compelled to offer forced labour, aid and construction materials. The Chin see this as a sign of occupation and control and the military's attempt to tighten its hold over Chin society. In addition to destroying crosses the military has also gotten rid of Churches. Bibles have been seized by the military and burnt in recent years. Chin Christians have often been forcibly converted to Buddhism. When Chin children are sent to Buddhist monasteries for schooling, they have on occasions been forced to participate in Buddhist forms of worship.

Leading expert on Burmese affairs, Kawanami writes, 'The Myanmar government has concentrated its efforts to unite and develop the country by appropriating Buddhism as a hegemonizing ideology and co-opting monastic members to work as missionaries for the interest of the state. ${ }^{34}$ Church workers and pastors often face grave danger. Traditionally the Chin people do not permit alcohol in their society but the military on occasions has intentionally brought in large quantities of intoxicating liquor known as 'OB' which it has sold on the streets especially during Sundays. Rape by Burma Army soldiers in the Chin state is common. Chin language is forbidden in schools and Chin history is not taught. The emphasis seems to be on Burman history. Since the 1960's, there has been a suppression of minority languages within a centralised and militarised state associated with the Burman majority. In response to governmental suppression and what is often perceived as Burmanisation of national culture, many ethnic groups have sought to develop separate educational systems in order to preserve and reproduce minority languages and culture. ${ }^{35}$

\section{The Rohingya}

The Rohingya people live in south west Burma in a province that used to be called the Arakan state but now it is called the Rakhine state with Sittwe as its capital city. The Rohingya people are predominantly a Bengali Muslim community who have lived in the Arakan province for generations. However, their origins have been strongly contested by various academics and analysts. Some believe that they have a secret plot to create a Muslim state. The Rohingya people claim that they have lived in the Arakan for centuries and claim that Muslim kings ruled the Arakan in 1430 for over a hundred years. It is believed that they came to the Arakan province in different phases. Some came as traders and merchants. Some came as conquerors. Some came as victims of pirates and still others came in peaceful pursuits. Francis Wade writes 'They came in boats as traders from India and Persia who set up a string of small colonies along the western and southern coastlines. ${ }^{, 36}$ 
'The Rohingya crisis began shortly after the independence of Myanmar when the government attempted to deprive them of their right to citizenship through the Union Citizenship Act, 1948. ${ }^{37}$ Thousands have fled to neighbouring Bangladesh to get away from the crisis-_stricken province. Thousands more live in dire circumstances in temporary shelters and unregistered camps or settlements. Many are dispersed amongst villages around Teknaf, Ukhiya and the southern Chittagong part of Bangladesh. They have often taken to the high seas in very flimsy boats and have often been referred to as the boat people. They have almost no access to healthcare or education. Throughout recent history they have been oppressed by the Burmese state and have been subjected to racial and religious discrimination. Azeem Ibrahim writes, 'ever since Burma became independent in 1948 they have been targeted whenever ambitious or desperate politicians need to deflect attention from other matters. Both government officials and party leaders have called for their expulsion from their homeland, and the main opposition ignores their plight. ${ }^{38}$

Without citizenship rights the Rohingya people face restriction in almost all spheres of life. Forced labour, rape and confiscation of land is very common in the Rakhine. Despite being from a Muslim background and despite ethnic commonalities, they are not always welcome in Bangladesh. They have been surviving stateless. They have been subjected to hostility on both sides of the border. In recent years there has been a lot of tension between Buddhist and Muslim communities in the Rakhine state. 'In 2012 violence broke out in Myanmar's western Rakhine state between local Buddhists and Muslim communities. The violence stemmed from a mixture of factors related to widespread poverty, perceived illegal immigration and opposition to permission granted to Muslims in Rakhine state to participate in electoral processes...Following the 2012 violence, four laws popularly referred to as a package of 'Laws for Protection of Race and Religion' were soon proposed by the Buddhist nationalist Ma Ba Tha or Association for the Protection of Race and Religion, which conducted a nationwide signature campaign pressurising the president and government to pass the laws. ${ }^{, 39}$

\section{Indian Media Reporting o 9 n tThe Rohingya Crisis}

The Telegraph is a prominent English based language newspaper based in the eastern Indian city of Kolkata. Since Kolkata is in the extreme eastern part of India geographically it is quite close to both Bangladesh and the Rakhine province in Myanmar where the Rohingya crisis has been taking place. Journalists from Kolkata have actively reported on this issue in 2017. This section of the paper will try to engage with some of the articles which have been published in $t \underline{T h e}$ Telegraph particularly in 2017.

Since the Japanese occupation of Burma in 1942, the Buddhist Muslim divide had widened. The Muslims had been pro-British and the Burmese nationalists as discussed earlier had initially entered into an alliance with Japan. The Rohingyas had wanted to be incorporated in what used to be East Pakistan in 1947 but this was not to be. Since then the Rakhine province has witnessed a low intensity insurgency whose character has gradually become religious with the involvement of Islamist groups from Pakistan, Saudi Arabia, Bangladesh and of late India. ${ }^{40}$ 
Around the time when former UN secretary general Kofi Annan flew to Myanmar with the final report of the Advisory Commission on the Rakhine state, "the military wing chief of the fledgling but highly radicalised Arakan Rohingya Salvation Army, Hafiz Tohar received a call from Brigadier Ashfaq of Pakistan's Inter-Services Intelligence: attacks must start immediately after Annan presents his report. ${ }^{, 41}$

Tohar himself had trained in Pakistan in a Laskhar e Toiba camp in 2015-16 after his recruitment by Abdul Qudoos Burmi, heading the Harkat-ul-jihad al Islami Arakan. Around 38,-000 Rohingya have crossed into Bangladesh from Myanmar just a week after the Rohingya insurgents had attacked police posts and an army base in the Rakhine, prompting clashes and a military counter offensive. Both Myanmar's security officials and insurgents from the Rohingya ethnic minority have been accusing each other of burning down villages and of committing atrocities in the Rakhine state. Hundreds have died in the armed clashes. The violence has triggered a flood of refugees crossing mostly on foot into Bangladesh, though some were fleeing in wooden boats. 'The refugees flowing into Bangladesh have been predominantly women and kids. ${ }^{42}$ They arrive starved with dehydrated babies and still have many more miles to go before they can reach a refugee camp. Fights have erupted over food and water. People have been arriving on boats or fishing trawlers on Shah Porir Dwip island, a short distance from the mouth of the Naf river that separates the two countries. Many have collapsed on the beach from motion sickness and dehydration.

The treatment of Myanmar's roughly 1.1 million Muslim Rohingya has been one of the biggest challenges for Aung Saan Suu Kyi who has come under tremendous international pressure for not speaking out on behalf of the minority that has long complained of persecution. The security forces argue that they are fighting a legitimate battle against terrorists who have been responsible for a string of attacks on police posts but international rights groups argue that these security forces are actually trying to force the Rohingya's out of the country with a campaign of arson and killings. The situation in the Rakhine state has often been described as ethnic cleansing by $\mathrm{U}_{-} \mathrm{N}_{\underline{-}}$ human rights officials. 'While Bangladesh has faced criticism over plans to ship off some of those refugees to a tiny island that is submerged for part of the year, it has along with most others in South Asia demanded that Myanmar do more to stanch the outflow of refugees and address the concerns of the Rohingyas. India, on the other hand, has publicly backed Suu Kyi's government to the full, while the differences within the Modi administration have emerged in the form of confused messaging. ${ }^{, 43}$ In relation to India, Balaji writes 'a draft affidavit that got leaked by mistake suggests the Centre wanted to deport an estimated 40,-000 Rohingya Muslim immigrants and was about to tell the Supreme Court that they were a security risk, demographic threat and a drain on resources. ${ }^{, 44}$ The Narendra Modi government decided to grant citizenship to over one lakh Chakma and Hajong refugees who are mostly Buddhists and Hindus in India's northeast amid growing international concern over its plan to deport 40,-000 Muslim Rohingya settlers. ${ }^{45}$ The fleeing of so many Rohingya's to neighbouring Bangladesh to escape a military offensive has now raised questions in the international community about Myanmar's transition to civilian rule under Aung San Suu Kyi.

\section{Conclusion}


The Rohingya humanitarian crisis is most certainly one of the biggest challenges a country has faced in recent times. But this grave situation should not be seen in isolation. It needs to be located within a certain historical context and should be seen as a part of a historical continuum. Problematic race relations did not start in Myanmar in recent years. It started with the introduction of British colonial policies such as divide and rule in the country about a hundred and fifty years ago. British colonisers often favoured ethnic minority groups like the Kachin and the Karen who fought alongside the British in the Second World War. The British also favoured minority groups in education and service. The Burman majority was almost excluded from the army and state institutions. Britain's attempt to rationalise administrative structures by destroying traditional political institutions like the monarchy in the Burman core and keeping intact the traditional political institutions in the more ethnic minority peripheral parts of the country only strengthened ethnic cleavages and worsened racial divides.

But the British are not the only ones to blame. After independence, in the post-1948 period, we see how Burman politicians have tried to use Buddhism to unify a fractured country with fissiparous tendencies. This obviously made many ethnic and religious minorities within the country feel excluded. Furthermore, xenophobic tendencies strengthened in the sixties with the arrival of Ne Win. Disintegration under the impact of colonialism, political turmoil under decades of military rule and deadlock under martial law have all collectively created a situation of emergency and tremendous crisis in which Myanmar finds itself today.

There are no quick or straightforward solutions to this very complex and serious situation. Political activists and reformers would need to seriously challenge authoritarianism in all its shapes and form. The men who were associated with the Tatmadaw maybe out of uniform but are they still ruling the country from the side lines? Meaningful democracy needs to be introduced in the country very urgently. Reforms capable of entrenching and sustaining real democracy need to be sponsored. Issues of social exclusion and economic development need to be dealt with especially in the more peripheral parts of the country where most ethnic minorities live. Finally, the political elite need to address issues of social justice and national reconciliation.

\section{NOTES}

${ }^{1}$ N.Cheesman, 'How in Myanmar 'National Races' Came to Surpass Citizenship and Exclude Rohingya,' Journal of Eonteperary Contemporary Asia, 47(3), 2017, pp.461-483.

2 I.Holliday, Burma Redux: Global Justice and the Quest for Political Reform in Myanmar, Columbia University Press, New York, 2011, p. 26.

${ }^{3}$ P.Church, A Short History of South East Asia, 2017, Wiley: Singapore.

${ }^{4}$ I.Holliday, $\underline{\text { op. cit., 2011, p. } 29 .}$.

${ }^{5}$ I.Holliday, 'Ethnicity and Democratization in Myanmar', Asian Journal of Political Science, 18(2), 2010, pp. 116-117.

\begin{tabular}{l}
\hline Formatted: Font: Italic \\
\hline Formatted: Font: Italic \\
\hline Formatted: Font: Italic \\
\hline Formatted: Font: Italic \\
\hline Formatted: Font: Italic \\
\hline Formatted: Font: Italic \\
\hline
\end{tabular}


${ }^{6}$ R.Cockett, Blood, Dream and Gold: The Changing Face of Burma, Yale University Press, New Haven/London, 2015, p. 16.

${ }^{7}$ G.Klinken and S.M.T, Aung, 'The Contentious Politics of Anti-Muslim Scapegoating in Myanmar', Journal of Contemporary Asia, 47(3), 2017, p. 357.

${ }^{8}$ S.Tucker, Burma: The Curse of Independence, Pluto Press, London, 2001, p. 81.

${ }^{9}$ P.Strefford, 'How Japan's Post War Relationship with Burma was shaped by Aid', Asian Affairs, 41(1), 2010, p.35.

${ }^{10}$ D.Steinberg, ed, In Search of South East Asia: A Modern History, University of Hawaii Press, Honolulu, 1985/87, p. 394.

${ }^{11}$ A.Cotterell, Asia: A Concise History, John Wiley and Sons: Singapore, 2011, p. 415.

12 P.Popham, The Lady and the Generals: Aung San Suu Kyi and Burma's Struggle for Freedom, Rider, London, 2016, p. 301.

${ }^{13}$ D.Steinberg, Burma/Myanmar: What Everyone Needs to Know, Oxford University Press, Oxford/New York, 2013, p. 21.

${ }^{14}$ I.Holliday, 'Addressing Myanmar's Citizenship Crisis', Journal of Contemporary Asia, 2014, 44(3), p. 418.

15 A.C.Guan, 'Political Legitimacy in Myanmar: The Ethnic minority Dimension' Asian Security, 3(2), 2007, p. 127.

${ }^{16}$ M.S.Wong, 'Linguistic, Religious and Ethnic Identities as Pathways to Peace: Views from Eight Lisu, Karen, Kachin, and Chin Seminary Teachers in Myanmar', Asian Englishes, 19(3), 2017, p. 211.

${ }^{17}$ A.Cotterell, A History of South East Asia, Marshall Cavendish Editions, Singapore, 2014, p. 302.

${ }^{18}$ I.Holliday, 'Beijing and the Myanmar Problem', The Pacific Review, 22(4), 2009, p. 488.

${ }^{19}$ T.Myint-U, The River of Lost Footsteps: A Personal History of Burma, 2007, London: Faber and Faber, London, 2007p. 296.

${ }^{20}$ A.P. Macdonald, 'From -military rule to Electoral Authoritarianism: The Reconfiguration of Power in Myanmar and its Future', Asian Affairs: Aan American Review, 40(1), 2013, p. 21.

${ }^{21}$ L._Brooten and Y._Verbruggen, 'Producing the News: Reporting on Myanmar's Rohingya Crisis', Journal of Contemporary Asia, 2017, 47(3), p441.

${ }^{22}$ C. Win and T. Kean, 'Communal Conflict in Myanmar: The Legislature's Response, 20122015', Journal of Contemporary Asia, 47(3), 2017, p. 413.

${ }^{23}$ M.A. Myoe, 'The Soldier and the State: the Tatmadaw and Political Liberalisation in Myanmar since 2011', South East Asia Research, 22(2), 2014, p. 241.

\section{Formatted: Font: Italic}

Formatted: Font: Italic

Formatted: Font: Italic

Formatted: Font: Italic

Formatted: Font: Italic

Formatted: Font: Italic

Formatted: Font: Italic

Formatted: Font: Italic

Formatted: Font: Italic

Formatted: Font: Italic

Formatted: Font: Italic

Formatted: Font: Italic

Formatted: Font: Italic

Formatted: Font: Italic

Formatted: Font: Italic

Formatted: Font: Italic

Formatted: Font: Italic

Formatted: Font: Italic

Formatted: Font: Italic 
${ }^{24}$ R. Pederson, The Burma Spring: Aung San Suu Kyi and the New Struggle for the Soul of a Nation, Pegasus, New York, 2015, pp.3-4.

${ }_{2525}$ M.J._Walton, 'The Wages of Burman-ness: Ethnicity and Burman Privilege in Contemporary Myanmar', Journal of Contemporary Asia, 43(1), 2013, p..1.

${ }^{26}$ T. Myint-U, Where China meets India: Burma and the new Crossroads of Asia,2011,Faber and Faber, London, 2011, p. 106.

27 M._Schissler, M._Walton and P.P._Thi, 'Reconciling Contradictions: Buddhist-Muslim Violence, Narrative Making and Memory in Myanmar' Journal of Contemporary Asia, 2017, 47(3), pp. 376-377

${ }^{28}$ A.South, 'Hybrid Governance and the Politics of Legitimacy in the Myanmar Peace Process', Journal of Contemporary Asia, 2018, 48(1), p. 50.

${ }^{29}$ E.Han, 'Geopolitics, Ethnic Conflicts along the Border, and Chinese Foreign Policy Changes toward Myanmar', Asian Security, 2017, 13(1), p. 60.

30 N.Farelly, 'Cooperation, Contestation, Conflict: Ethnic Political Interests in Myanmar Today’ South East Asia Research, 22(2), 2014, pp.251-252.

31 D.Brenner, 'Inside the Karen Insurgency: Explaining Conflict and Conciliation in Myanmar's Changing Borderlands', Asian Security, 2018, 14(2), p. 85.

${ }^{32}$ B.Rogers, Burma: A Nation at the Crossroads, Rider Books, London, 2012, p. 52.

${ }^{33}$ B.Lintner, Great Game East: India, China and the Struggle for Asia most Volatile Frontier, Harper Collins, New Delhi, 2012, p. 247.

${ }^{34}$ H.Kawanami, Renunciation and Empowerment of Buddhist Nuns in Myanmar-Burma: Building a community of Female Faithful, 2013, Brill, Leiden/Boston, p. 236.

${ }^{35}$ M. Lall and A.South, 'Comparing models of non-state ethnic education in Myanmar: The Mon and Karen National Education Regimes', Journal of Contemporary Asia, 2014, 44(2), p304.

${ }^{36}$ F.Wade, Myanmar's Enemy Within: Buddhist Violence and the Making of the Muslim Other, 2017, Zed, London, p17.

37 J.Alam, 'The Rohingya Minority of Myanmar: Surveying their Status and Protection in International Law', International Journal on mMinority and Group Rights, 2018, 25(2), p160.

38 A. Ibrahim, The Rohingyas: Inside Myanmar's Hidden Genocide, 2016, Hurst, London, 2016, p. 1

${ }^{39}$ G.McCarthy and J.Menager, 'Gendered Rumours and the Muslim Scapegoat in Myanmar's Transition', Journal of Contemporary Asia, 2017, 47(3), 2017, pp. 396-397.

${ }^{40}$ S.Dasgupta, 'Keep a Safe Distance: The Rohingya Insurgency must not become India's Problem', The Telegraph, Kolkata, 07.09.2017, p.12.

\section{Formatted: Font: Italic}

Formatted: Font: Italic

Formatted: Font: Italic

Formatted: Font: Italic

Formatted: Font: Italic

Formatted: Font: Italic

Formatted: Font: Italic

Formatted: Font: Italic

Formatted: Font: Italic

Formatted: Font: Italic

Formatted: Font: Italic

Formatted: Font: Italic

Formatted: Font: Italic

Formatted: Font: Italic

Formatted: Font: Italic

Formatted: Font: Italic

Formatted: Font: Itali 
${ }^{41}$ S.Bhaumik, 'Profile of a Plot', The Telegraph, Kolkata, 04.10.2017, p. 14.

${ }^{42}$ H.Beech, 'For Rohingya, Dying is not Done', The Telegraph, Kolkata, 04.09.2017, p. 2.

43 C.S.Kasturi, 'Restraint advice to Yangon on Rohingyas', The Telegraph, Kolkata, 10.09.2017, p. 4 .

${ }^{44}$ R.Balaji, 'Mistake reveals stand on Rohingya', The Telegraph, Kolkata, 15.09.2017, p. 1.

${ }^{45}$ I.A.Siddiqui, 'Citizenship to a lakh refugees: Centre Decision on Chakma and Hajong amid Rohingya row', The Telegraph, Kolkata, 14.09.2017, p.6.
Formatted: Font: Italic

Formatted: Font: Italic

Formatted: Font: Italic

Formatted: Font: Italic

Formatted: Font: Italic 